\title{
Antimicrobial Resistance and Virulence Factor of Streptococcus dysgalactiae Isolated from Clinical Bovine Mastitis Cases in Northwest China
}

\author{
Jirao Shen \\ Xiaohu Wu (D) \\ Yayuan Yang \\ Yanan Lv \\ Xinpu Li \\ Xuezhi Ding \\ Shengyi Wang \\ Zuoting Yan \\ Yong Yan \\ Feng Yang \\ Hongsheng $\mathrm{Li}$
}

Lanzhou Institute of Husbandry and Pharmaceutical Sciences, Chinese Academy of Agricultural Sciences, Lanzhou, People's Republic of China
Correspondence: Feng Yang; Hongsheng Li Tel +86 039l-2I I5262; +86 039l-2I64I83 Email yangfeng@caas.cn; lihsheng@sina.com
Objective: Streptococcus dysgalactiae is a major pathogen in bovine mastitis. The purpose of this study was to survey the prevalence, antimicrobial resistance, as well as the spread of resistance and virulence-associated gene of $S$. dysgalactiae.

Methods: A total of $60 \mathrm{~S}$. dysgalactiae strains were obtained from 830 milk samples from Holstein cows with clinical mastitis. Antimicrobial resistance was examined by the disk diffusion method. Antimicrobial resistance and virulence genes were investigated by PCR, agarose gel electrophoresis and 16S rRNA gene sequencing.

Results: All isolates were resistant to tetracycline and showed a high level of resistance to aminoglycoside antibiotics, where $81.67 \%$ of the strains were multi-resistant to these ten sorts of antibiotics. In addition, the most prevalent resistance gene in $S$. dysgalactiae was aphA-1 (98.33\%), followed by blaTEM (96.67\%), ermB (83.3\%), aadA1/aadA2 (78.33\%) and tetL $(73.33 \%)$. Totally, seven virulence genes with 25 combination patterns were detected in these isolates, and each isolates harbored at least one virulence gene. $21.67 \%$ of the isolates carried three or more virulence genes, while one strain with seven virulencerelated genes and belonged to $c f b+\operatorname{lm} b+e n o+n a p r+b c a+s c p B+c y l$.

Conclusion: These findings indicate that $S$. dysgalactiae isolated from clinical bovine mastitis cases in Northwest China show a variety of molecular ecology and are highly resistant to antibiotics commonly used in dairy farms. This research will help investigators better understand the pathophysiology $S$. dysgalactiae in bovine mastitis and choose the appropriate antibiotics to treat mastitis.

Keywords: Streptococcus dysgalactiae, bovine mastitis, antimicrobial resistance, virulence gene

\section{Introduction}

Bovine mastitis is one of the most prevalent and costly diseases concerning the dairy industry worldwide. ${ }^{1}$ It is a kind of topical inflammation reaction, mainly due to the invasion of mammary gland tissue by microorganism. ${ }^{2,3} S$. dysgalactiae has become the major cause behind several mammalian infections, which can lead to streptococcal mastitis/endometritis in domestic mammals and skin lesions, meningitis, and bacteremia in humans. ${ }^{4}$ In Swedish and other countries, it is recognized as the most common causative pathogens of bovine mastitis. ${ }^{5-7}$ Besides, $S$. dysgalactiae is generally considered as an environmental pathogen. Although major advances have been seen in some prevent procedures of preventing and controlling mastitis, it exhibits less effective against the environmental pathogens, which produces more difficulty to control S. dysgalactiae. ${ }^{8-10}$ 
Antimicrobial agents have always been used to prevent and control of mastitis around the world. ${ }^{11,12}$ However, the abuse of antibiotics leads to antimicrobial resistance among causative agents and causes reactions in humans allergic to antimicrobials. This phenomenon is becoming more and more serious, which is coming to our notice. Previous investigations have confirmed that S. dysgalactiae possesses phenotypic and genotypic resistance to some common antimicrobial agents, such as Kanamycin (aphA-1, aphA-2, aphA-3, aadAl/aadA2, aad-6), $\beta$-lactam antibiotics (blaTEM, blaIMP, blaSPM1), erythromycin (ermA, ermB, ermC, mefE), streptomycin $(r r s)$, tetracyclines $(t e t D$, tet $K$, tet $L$, tet $M$, tet $O)$, etc. ${ }^{13,14}$ The virulence-associated determiners of $S$. dysgalactiae play a crucial role in the pathogenesis of the causative agents, including $\alpha$-enolase, nephritis-associated plasminogen-binding receptor, $\beta$ - hemolysin, Lamining-binding Protein. ${ }^{14-16}$ But in fact, little is known about these characteristics about the $S$. dysgalactiae isolated from bovine mastitis in Northwest, China. Therefore, the aim of this study is to investigate the antimicrobial resistance, resistance genes and virulence genes of it.

\section{Materials and Methods}

\section{Sample Collection}

Eight hundred and thirty (830) clinical mastitis milk samples were aseptically collected between 2016 and 2019. Herds selected in this study were from large-scale commercial dairy farms with good breeding administration measures; Mechanized Milking System is adopted by all the cattle farms. Each farm has 2000-3000 livestock with a minimum of 500 lactating Holstein-Friesian cows, (Ningxia Prov. $=342$ samples from 10 farms, Gansu Prov. $=196$ samples from 7 farms, Xinjiang Prov. $=170$ samples from 6 farms, Shaanxi Prov. $=122$ samples from 4 farms). The incidence of bovine mastitis in cattle farm ranges from $2 \%$ to $10 \%$, and the parity of sick cows is about 4 to 5. In Northwest China, the incidence is higher from January to February and from June to September, so the samples were mainly collected during this period.

The clinical mastitis was confirmed by the California Mastitis Test (CMT). All of these farms employed veterinarians who had received professional training on sampling procedures and aseptic techniques for collecting samples. After sampling, the veterinarians disinfected the breasts of dairy cows with $75 \%$ ethanol and milk samples were transported to the laboratory at $4{ }^{\circ} \mathrm{C}$ for microbiological culture.

The sampling process was similar to normal commercial milking and met the requirements of animal welfare. This study does not involve animal experiments therefore ethical approval for this study was not needed.

\section{Microbiological Culture and Identification}

A volume of $20 \mu \mathrm{L}$ of each sample was plated on sheep blood agar (Huan kai, Guangdong, China) at $37^{\circ} \mathrm{C}$ aerobically for 24 to $48 \mathrm{~h}$. It was considered as cultured positive if 1 or more colonies were observed. Milk samples with 3 or more species were considered contaminated, unless Staphylococcus aureus or Streptococcus agalactiae were isolated. ${ }^{7}$ After growth, every single colony with different morphology was sub-cultured on blood agar. Another optional sub-culture was conducted if different morphological colonies grew on the same plate. A single colony was enrichment cultured in nutrient broth at $37{ }^{\circ} \mathrm{C}$ for 24 to $48 \mathrm{~h}$ and stored with $15 \%$ glycerol at $-80{ }^{\circ} \mathrm{C}$.

The colony was cultured in $2 \mathrm{~mL}$ of Tryptone Soya broth (TSB; Oxoid, UK) at $37{ }^{\circ} \mathrm{C}$ for $24-48 \mathrm{~h}$. Then, the genomic DNA was extracted using the Bacterial DNA Kit (Omega, USA) following the manufacturer's protocol. Next, 16S rRNA gene sequencing (Tsingke, Xi'an, China) was used to identify the strains by the PCR amplified products of the extracted DNA.

\section{Antimicrobial Susceptibility Testing}

Antimicrobial susceptibility against 13 antimicrobial agents were determined by disc diffusion method on Mueller-Hinton agar (MHA; Oxoid, United Kingdom) supplemented with 5\% sheep blood (Solarbio, Beijing, China) according to the Clinical and Laboratory Standards Institute, and E-test detected meropenem. ${ }^{17}$ The commercially available discs (Oxoid, United Kingdom) used in this study included cefepime $(30 \mu \mathrm{g})$, cefotaxime $(30 \mu \mathrm{g})$, vancomycin $(30 \mu \mathrm{g})$, erythromycin $(15 \mu \mathrm{g})$, tetracycline $(30 \mu \mathrm{g})$, levofloxacin $(5 \mu \mathrm{g})$, chloramphenicol $(30 \mu \mathrm{g})$, clindamycin $(2 \mu \mathrm{g})$, linezolid $(30 \mu \mathrm{g})$, kanamycin $(30 \mu \mathrm{g})$, gentamycin $(10 \mu \mathrm{g})$, streptomycin $(10$ $\mu \mathrm{g}), \quad$ sulphamethoxazole $(23.75 \mu \mathrm{g})$. E-test strip (Liofulchem, Italy) of meropenem ranged from $0.016 \mu \mathrm{g} /$ $\mathrm{mL}$ to $256 \mu \mathrm{g} / \mathrm{mL}$. For those which did not have a reference breakpoint of resistance to Streptococcus spp., the resistant breakpoints referred to either an antimicrobial of the same antimicrobial drug class or another pathogen group. ${ }^{13}$ 


\section{Antimicrobial Resistance and Virulence Genotyping}

The antimicrobial resistance and virulence genes were tested by simplex PCR amplification. Most resistance genes were from references except for vancomycin-related and linezolidrelated resistance genes were designed by Primer 5.0 software. The detailed information of the primers is shown in Tables 1 and 2. All primers were synthesized by Tsingke Biological Technology (Xi'an, China). The system for detecting resistance and virulence genes was $25 \mu \mathrm{L}$, consisting of $22 \mu \mathrm{L}$ T3 Super PCR Mix (Tsingke, Xi'an, China), $1 \mu \mathrm{L}$ DNA sample material, $1 \mu \mathrm{L}$ forward, and $1 \mu \mathrm{L}$ reverse primers. The reaction following the manufacturer's protocol and run in a thermal cycler (Biometra T Advanced, German). The PCR products $(5 \mu \mathrm{L})$ were analyzed by electrophoresis on $1 \%$ agarose gel and stained with Gel-red (Tsingke, Xi'an, China). The results were visualized and photographed by a UV transilluminator. In addition, DNA sequencing (Tsingke, Xi'an, China) identify was used to further identify the PCR amplified products of the resistance and virulence genes, and the gene sequence was compared in the NCBI gene bank. Hence, electrophoresis and DNA sequencing technique were used to determine whether the strain carried the corresponding resistance and virulence gene.

\section{Results}

\section{Isolation and Identification of S. dysgalactiae}

In this study, the similarity among the sequencing results of all isolates was $\geq 99 \%$. In all the milk samples, a total of 91 samples have no bacteria growth, which were regard as cultured negative. Except that, 31 samples were defined as contaminated. The rest of 708 milk samples were cultured positive, including Escherichia coli (143/830, 17.23\%), Klebsiella spp. (76/830, 9.15\%), Coagulase negative staphylococci $(68 / 830,8.2 \%)$, S. agalactiae (72/830, 8.7\%), S. aureus (113/830, 13.61\%), S. dysgalactiae (60/830, 7.23\%), Enterobacter spp. (53/830, 6.39\%), Streptococcus uberis (21/830, 2.53\%), Pseudomonas spp. (32/830, 3.86\%), Trueperella pyogenes (17/830, 2.05\%), Aerococcus viridans $(23 / 830,2.78 \%)$ and mixed-culture $(30 / 830,3.61 \%)$.

\section{Antimicrobial Susceptibility Testing}

The phenotypic resistance of fourteen antimicrobial of S. dysgalactiae is shown in Table 3. The resistance rate of tetracycline was the highest, up to $100 \%$, followed by aminoglycosides (greater than 70\%). Each of the resistance rates of chloramphenicol, erythromycin, sulphamethoxazole, levofloxacin, vancomycin, linezolid, cefotaxime, and cefepime was less than half, only $33.33 \%, 36.67 \%, 18.33 \%$, $13.33 \%, 46.67 \%, 20 \%, 45 \%, 11.67 \%$, respectively. In addition, all isolates were susceptible to meropenem. Notably, $81.67 \%$ of the strains were multidrug-resistant to these 14 antibiotics, and 2 isolate strains were only sensitive to linezolid and meropenem.

\section{Genotypic Resistance Profiles of \\ S. dysgalactiae}

The sequencing results of all resistance gene were $100 \%$ similar. The resistance gene bands were clearly recorded according to the electrophoresis results, which revealed the same results as DNA sequencing. As shown in Table 3, the most frequently detected antimicrobial resistance gene was aphA-1 (98.33\%), followed by blaTEM (96.67\%), ermB (83.33\%), aadA1/aadA2 (78.33\%), tetL (73.33\%), aphA-3 (65\%), cat1 $(63.33 \%)$, cat2 $(68.33 \%)$, tetS $(45 \%)$. Moreover, tetracyclines resistance genes (tetD, 11.67\%; tet $M, 8.33 \%$; tet $O, 10 \%$ ), erythromycin resistance genes (mefE, 10\%), the gene of aad6 (3.33\%) about aminoglycosides, and the gene of blaSHV (1.67\%) about $\beta$-Lactam antibiotics were also amplified. Additionally, vanA (6.67\%), vanB (8.33\%), vanC1/C2 (1.67\%) resistance genes related to vancomycin, and optrA $(1.67 \%)$, poxtA $(25 \%)$ related to linezolid were detected as well. However, none of the stains were positive for the resistance genes related to the tetracyclines (tetK), aminoglycosides (aphA2), erythromycin (ermA, ermC), vancomycin $(\operatorname{Van} C 2 / C 3)$, and linezolid (Cfr). Furthermore, the rpsL and rrs for streptomycin resistance gene were not detected in any of the strains.

\section{Genotypic Virulence Profiles of S. dysgalactiae}

All virulence gene sequencing results were $100 \%$ similar. The result of agarose gel electrophoresis was corresponded with the DNA sequencing. The results showed that all isolates carried napr, and $36.67 \%$ carried the gene $c f b$. The genes eno, lmb, bca, scpB and $c y l$ were detected as well, in $16.67 \%, 3.33 \%, 6.67 \%, 18.33 \%$ and $13.33 \%$ of the isolates, respectively. However, the $b a c$ gene was negative in any isolate. In this study, all tested isolates had at least one virulence gene, and $21.67 \%$ of those harbored three virulence-associated genes, and one isolate carried seven genes. 
Table I Target Resistance Gene Information

\begin{tabular}{|c|c|c|c|c|}
\hline Antimicrobial Drug Class & Target Gene & Primer Sequence $\left(5^{\prime} \rightarrow 3^{\prime}\right)$ & Product Size (bp) & References \\
\hline \multirow[t]{6}{*}{ Tetracyclines } & tet $D$ & $\begin{array}{l}\text { ATTACACTGCTGGACGCGAT } \\
\text { CTGATCAGCAGACAGATTGC }\end{array}$ & 1104 & Zhang et al. ${ }^{13}$ \\
\hline & tetK & $\begin{array}{l}\text { GTAGGATCTGCTGCATTCCC } \\
\text { CACTATTACCTATTGTCGC }\end{array}$ & 155 & Zhang et al. ${ }^{13}$ \\
\hline & tetL & $\begin{array}{l}\text { TGGTGGAATGATAGCCCATT } \\
\text { CAGGAATGACAGCACGCTAA }\end{array}$ & 229 & Zhang et al. ${ }^{13}$ \\
\hline & tet $M$ & $\begin{array}{l}\text { GTGGAGTACTACATTTACGAG } \\
\text { GAAGCGGATCACTATCTGAG }\end{array}$ & 359 & Zhang et al. ${ }^{13}$ \\
\hline & tetO & $\begin{array}{l}\text { ACGGARAGTTTATTGTATACC } \\
\text { TGGCGTATCTATAATGTTGAC }\end{array}$ & 171 & Zhang et al. ${ }^{13}$ \\
\hline & tet $S$ & $\begin{array}{l}\text { GAAAGCTTA CTATACAGTAGC } \\
\text { AGGAGTATCTACAATATTTAC }\end{array}$ & 229 & Zhang et al. ${ }^{47}$ \\
\hline \multirow[t]{4}{*}{ Macrolides } & ermA & $\begin{array}{l}\text { TCAGGAAAAGGACATTTTACC } \\
\text { ATACTTTTTGTAGTCCTTCTT }\end{array}$ & 432 & Zhang et al. ${ }^{13}$ \\
\hline & erm $B$ & $\begin{array}{l}\text { ATTGGAACAGGTAAAGGGC } \\
\text { GAACATCTGTGGTATGGCG }\end{array}$ & 442 & Zhang et al. ${ }^{47}$ \\
\hline & ermC & $\begin{array}{l}\text { TCAAAACATAATATAGATAAA } \\
\text { GCTAATATTGTTTAAATCGTCAA }\end{array}$ & 642 & Zhang et al. ${ }^{13}$ \\
\hline & mefE & $\begin{array}{l}\text { AGTATCATTAATCACTAGTGC } \\
\text { TTCTTCTGGTACTAAAAGTGG }\end{array}$ & 348 & Zhang et al. ${ }^{13}$ \\
\hline \multirow[t]{5}{*}{ Aminoglycosides } & aphA-I & $\begin{array}{l}\text { ATGGGCTCGCGATAATGTC } \\
\text { CTCACCGAGGCAGTTCCAT }\end{array}$ & 600 & Zhang et al. ${ }^{13}$ \\
\hline & $a p h A-2$ & $\begin{array}{l}\text { GAACAAGATGGATTGCACGC } \\
\text { GCTCTTCAGCAATATCACGG }\end{array}$ & 680 & Zhang et al. ${ }^{13}$ \\
\hline & $a p h A-3$ & $\begin{array}{l}\text { GGGGTACCTTTAAATACTGTAG } \\
\text { TCTGGATCCTAAAACAATTCATCC }\end{array}$ & 848 & Zhang et al. ${ }^{13}$ \\
\hline & aadA I/aadA2 & $\begin{array}{l}\text { GCAGCGCAATGACATTCTTG } \\
\text { ATCCTTCGGCGCGATTTTG }\end{array}$ & 282 & Zhang et al. ${ }^{13}$ \\
\hline & aad-6 & $\begin{array}{l}\text { AGAAGATGTAATAATATAG } \\
\text { CTGTAATCACTGTTCCCGCCT }\end{array}$ & 978 & Zhang et al. ${ }^{13}$ \\
\hline \multirow[t]{2}{*}{ Streptomycin } & rpsL & $\begin{array}{l}\text { GGCCGACAAACAGAACGT } \\
\text { GTTCACCAACTGGGTGAC }\end{array}$ & 501 & Zhang et al. ${ }^{13}$ \\
\hline & rrs & $\begin{array}{l}\text { GAGAGTTTGATCCTGGCTCAG } \\
\text { TGCACACAGGCCACAAGGGA }\end{array}$ & 1042 & Zhang et al. ${ }^{13}$ \\
\hline \multirow[t]{2}{*}{ Phenicols } & catl & $\begin{array}{l}\text { CTTGTCGCCTTGCGTATAAT } \\
\text { ATCCCAATGGCATCGTAAAG }\end{array}$ & 508 & Tian et al. ${ }^{14}$ \\
\hline & cat2 & $\begin{array}{l}\text { AACGGCAYGATGAACCTGAA } \\
\text { ATCCCAATGGCATCGTAAAG }\end{array}$ & 547 & Tian et al. ${ }^{14}$ \\
\hline$\beta$-Lactams & blalMP & $\begin{array}{l}\text { CTACCGCAGCAGAGTCTTTG } \\
\text { AACCAGTTTTGCCTTACCAT }\end{array}$ & 587 & Zhang et al. ${ }^{13}$ \\
\hline
\end{tabular}

(Continued) 
Table I (Continued).

\begin{tabular}{|c|c|c|c|c|}
\hline Antimicrobial Drug Class & Target Gene & Primer Sequence $\left(5^{\prime} \rightarrow 3^{\prime}\right)$ & Product Size (bp) & References \\
\hline & blaSHV & $\begin{array}{l}\text { ATGCGTTATATTCGCCTGTG } \\
\text { TTAGCGTTGCCAGTGCTCGA }\end{array}$ & 860 & Zhang et al. ${ }^{13}$ \\
\hline & blaSPM-I & $\begin{array}{l}\text { CCTACAATCTAACGGCGACC } \\
\text { TCGCCGTGTCCAGGTATAAC }\end{array}$ & 649 & Zhang et al. ${ }^{13}$ \\
\hline & blaTEM & $\begin{array}{l}\text { ATGAGTATTCAACATTTTCGTG } \\
\text { TTACCAATGCTTAATCAGTGAG }\end{array}$ & 860 & Zhang et al. ${ }^{13}$ \\
\hline & blavIM & $\begin{array}{l}\text { ATTCCGGTCGGAGAGGTCCG } \\
\text { GAGCAAGTCTAGACCGCCCG }\end{array}$ & 633 & Zhang et al. ${ }^{13}$ \\
\hline & mecA & $\begin{array}{l}\text { TGGCTATCGTGTCACAATCG } \\
\text { CTGGAACTTGTTGAGCAGAG }\end{array}$ & 310 & Zhang et al. ${ }^{13}$ \\
\hline \multirow[t]{4}{*}{ Glycopeptides } & $\operatorname{van} A$ & $\begin{array}{l}\text { TTCAGGCTCATCCTTCGG } \\
\text { TCCACCTCGCCAACAACT }\end{array}$ & 174 & \\
\hline & $\operatorname{Van} B$ & $\begin{array}{l}\text { TGAGCAGCAAATCCACAA } \\
\text { TCGCCTTCAATTACATCG }\end{array}$ & 210 & \\
\hline & VanCl/C2 & $\begin{array}{l}\text { TGCCTTATGTTGGTTGCC } \\
\text { TGGTGCTGGGACAGTGAT }\end{array}$ & 494 & \\
\hline & $\operatorname{VanC2/C3}$ & $\begin{array}{l}\text { TGACAAATCAAGCCAACC } \\
\text { GCACTGCGGAACAATAAG }\end{array}$ & 172 & \\
\hline \multirow[t]{3}{*}{ Oxazolidinones } & $C f r$ & $\begin{array}{l}\text { TATGGGAATGGGAGAAGC } \\
\text { AGGAGAACTGACGGTTGG }\end{array}$ & 436 & \\
\hline & optrA & $\begin{array}{l}\text { GGTGGTCAGCGAACTAAG } \\
\text { CGTTCAATCAAGCGTGTA }\end{array}$ & 341 & \\
\hline & poxtA & $\begin{array}{l}\text { ATAAGGTCGGTATTGTCG } \\
\text { TCTGCCTCATAGAAGTCG }\end{array}$ & 325 & \\
\hline
\end{tabular}

\section{Discussion}

S. dysgalactiae is one of the most ubiquitous Streptococcus species, invading mammary glands when appropriate conditions permit their activities. ${ }^{15}$ In this study, the proportion of $S$. dysgalactiae isolated from $\mathrm{CM}$ was $7.23 \%$. The results for the prevalence of $S$. dysgalactiae were similar to those of Finland, South Eastern Ethiopia, France and Portugal, ranging from $5.10 \%-8.80 \%$, but lower than a national epidemiological study in China. ${ }^{7,18-21}$ The prevalence difference may be due to sampling number, geographical location, season, and management strategies. Effective medication, monitoring the development of resistant and virulent strains in certain ecological niches, and detecting the antimicrobial susceptibility profiles and virulence factors of S. dysgalactiae are crucial for preventing and treating the bovine mastitis caused by this pathogen. ${ }^{15,22}$
This study found that the isolates showed high resistance to tetracycline, followed by streptomycin, kanamycin, gentamycin and clindamycin, similar to a Portuguese study. ${ }^{21}$ According to the permission of prescription drug in veterinary based on Announcement No.1997 of the Ministry of Agriculture of the People's Republic of China, many kinds of antimicrobials were permitted to use as antimicrobial drugs in veterinary medicine in China. ${ }^{23}$ Long-term and widespread use of antibiotics to treat bacterial infection will definitely enhance the occurrence of multidrug-resistant streptococcus isolates, which would have more chance to cause bovine mastitis in the same dairy farm. The tetracycline testing results are similar to a Chinese report but much higher than one study in China, in which 59\% Streptococcus spp. isolates are resistant to tetracycline. ${ }^{14,24}$ This phenomenon may be due to the 
Table 2 Target Virulence Gene Information

\begin{tabular}{|c|c|c|c|c|}
\hline Function Protein & Tar-Get Gene & Primer Sequence $\left(5^{\prime} \rightarrow 3^{\prime}\right)$ & Prodict Size (bp) & References \\
\hline$\alpha$-enolase & eno & $\begin{array}{l}\text { ATGTCAATTATTACTGATGT } \\
\text { CTATTTTTTTAAATTATAGA }\end{array}$ & 1308 & Kaczorek et al. ${ }^{34}$ \\
\hline Nephritis-associated plasminogen-binding receptor & napr & $\begin{array}{l}\text { GTTAAAGTTGGTATTAACGGT } \\
\text { TTGAGCAGTGTAAGACATTTC }\end{array}$ & 963 & Kaczorek et al. ${ }^{34}$ \\
\hline CAMP factor & $c f b$ & $\begin{array}{l}\text { ATGGGATTTTGGGATAACTAAGCTAG } \\
\text { AGCGTGTATTCCAGATTTCCTTAT }\end{array}$ & 193 & Tian et al. ${ }^{14}$ \\
\hline Lamining-binding Protein & $\operatorname{Imb}$ & $\begin{array}{l}\text { ACCGTCTGAAATGATGTGG } \\
\text { GATTGACGTTGTCTTCTGC }\end{array}$ & 572 & Tian et al. ${ }^{14}$ \\
\hline C $\alpha$ protein & $b c a$ & $\begin{array}{l}\text { TAACAGTTATGATACTTCACAGAC } \\
\text { ACGACTTTCTTCCGTCCACTTAGG }\end{array}$ & 535 & Tian et al. ${ }^{14}$ \\
\hline$C \beta$ protein & bac & $\begin{array}{l}\text { TGTAAAGGACGATAGTGTGAAGAC } \\
\text { CATTTGTGATTCCCTTTTGC }\end{array}$ & 530 & Tian et al. ${ }^{14}$ \\
\hline Streptococcal C5aïpeptidase- adhesion & $s c p B$ & $\begin{array}{l}\text { CCAAGACTTCAGCCACAAGG } \\
\text { CAATTCCAGCCAATAGCAGC }\end{array}$ & 591 & Tian et al. ${ }^{14}$ \\
\hline$\beta$-haemolisin & $c y l$ & $\begin{array}{l}\text { ACGGCTTGTCCATAGTAGTGTTTG } \\
\text { AACGACACTGCCATCAGCAC }\end{array}$ & 345 & Tian et al. ${ }^{14}$ \\
\hline
\end{tabular}

different sampling area and other streptococci resistance have been counted in their study. Conventionally, $S$. dysgalactiae has a high-level resistance to aminoglycoside antibiotics, because it is mainly used to treat gram-negative bacterial infection. The report implies that the resistance to commonly used antibiotics in dairy cow diseases of S. dysgalactiae isolated from dairy cow in China is seriously. We also find that $45 \% S$. dysgalactiae isolates are not sensitive to cefotaxime. The levels observed in this investigation are $10 \%$ higher than those observed by Zhang et al and Tian et al ${ }^{13,14}$ This may be due to the long-term and widespread use of $\beta$ lactam antimicrobials in this area. It is worth noting that vancomycin is considered the last line of defense against severe infections caused by gram-positive bacteria. $^{25}$ Strikingly, we found the $S$. dysgalactiae show resistance to vancomycin and linezolid for the first time. In addition, $81.67 \%$ of the strains are multidrug-resistant. This sensational result has to be noticed because it may be a highly resistant "superbug".

This study also detected the corresponding resistance genes. It was found that the proportion of resistance genes related to aminoglycosides was at a high level, which had plenty of potentials, leading to the high resistance rate of the antibiotic. Although all strains were tetracycline-resistant, the related-resistant gene was only found in $76.67 \%$ of the strains. Inversely, a few were showed resistance to erythromycin, but most of them harbored the corresponding resistance gene. This rather contradictory result may be due to the absence of gene expression, mutations in the ribosomal target or some resistance genes that have not been identified yet. $^{26-28}$ These results suggest that phenotypic resistance is not necessarily related to resistance genes. In addition, one interesting finding was that blaSHV gene, vancomycin (vanA, vanB, VanC1/C2) and linezolid (optrA, poxtA) relevant genes were detected for the first time in $S$. dysgalactiae isolated from bovine mastitis. Since $S$. dysgalactiae is considered as a latent emerging zoonotic pathogen, this research output consider a phenomenon where public health security may be threatened. $^{29}$

Antimicrobials are sometimes effective in vitro but ineffective when in vivo because of some invasiveness factors in the bacteria. ${ }^{30}$ Many virulence factors of Streptococcus are involved in the infection and colonization of host cells and the escape of the immune system. ${ }^{31}$ Genes napr and eno encoding binding host plasminogen protein, contribute to infect and colonize the host. ${ }^{31,32}$ Plasminogen recruitment to the bacterial surface has been reported as a key pathogenic mechanism to promote bacterial adhesion to cell surface. ${ }^{33}$ All isolates in this 


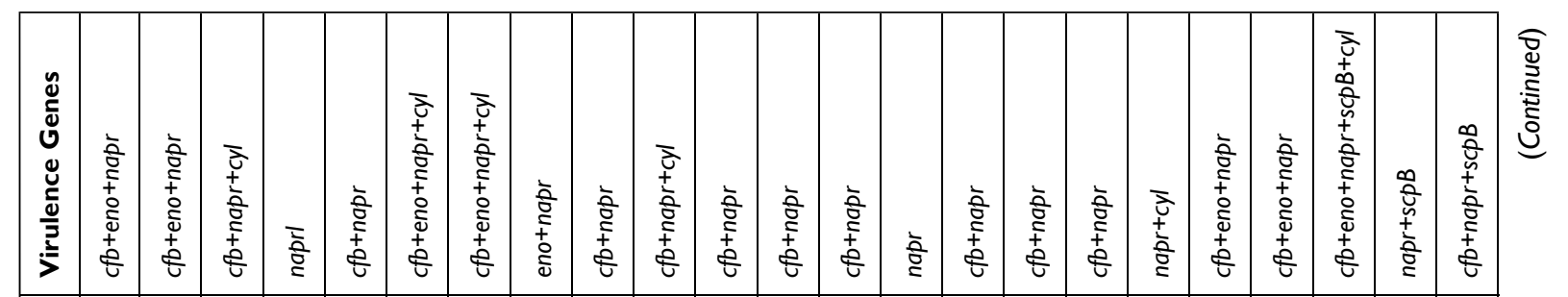

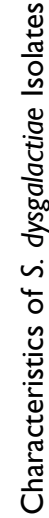

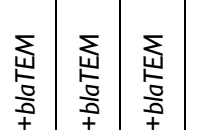

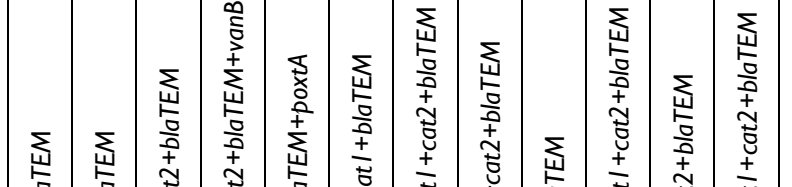

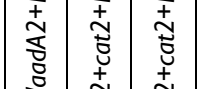

ran

:

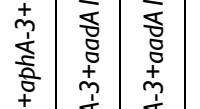

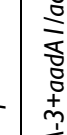

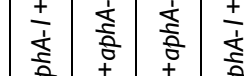

(

胥

نั

离

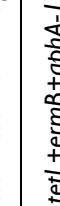

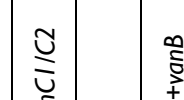

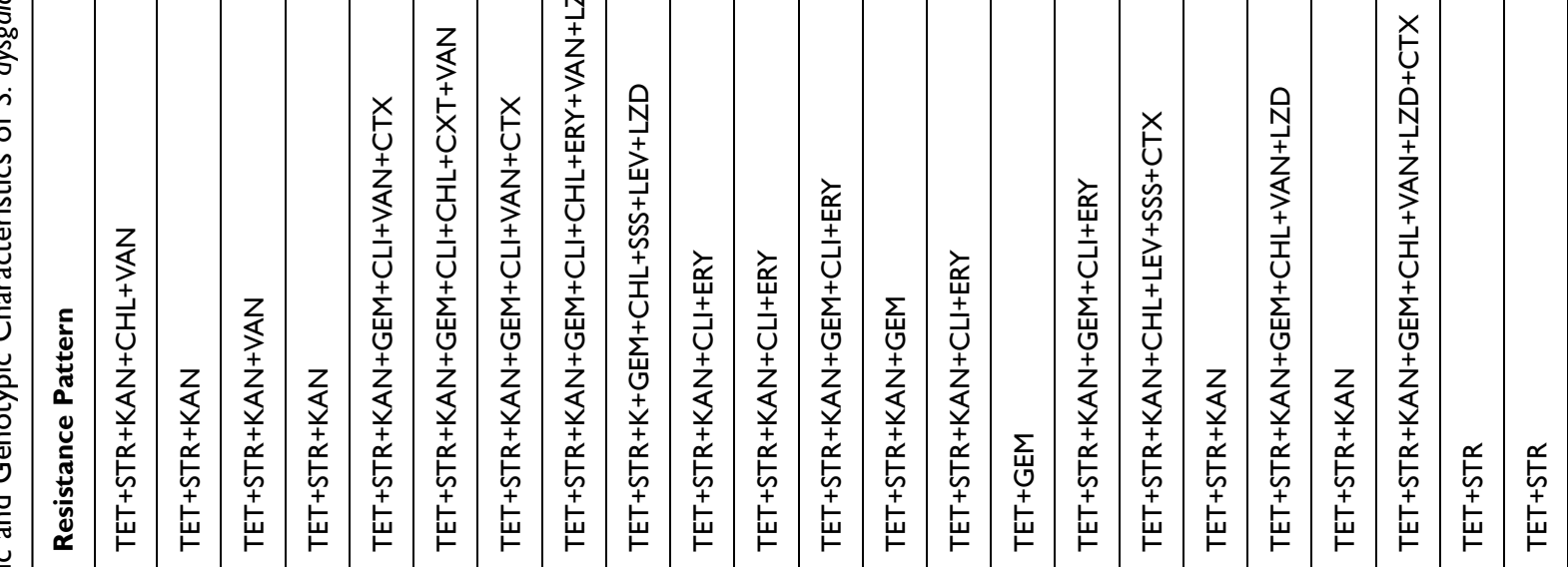

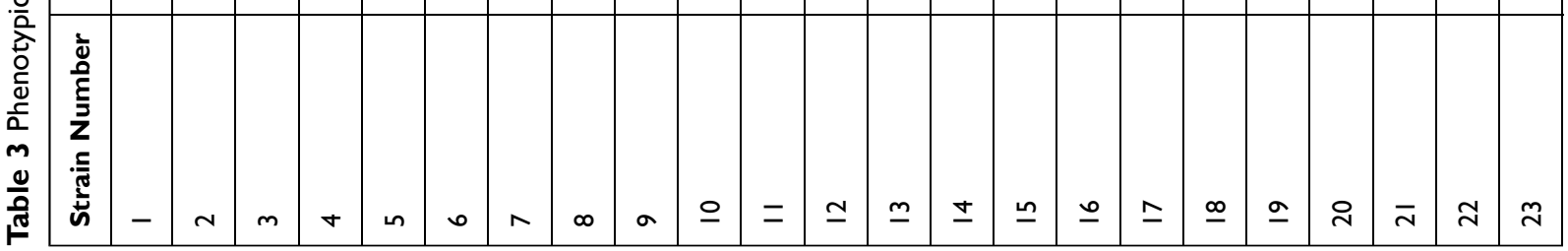




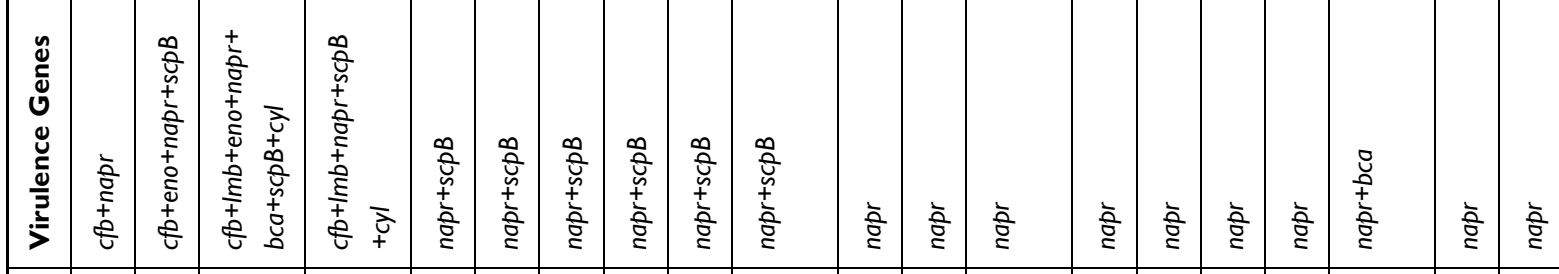

\begin{tabular}{|c|c|c|c|c|c|c|c|c|c|c|c|c|c|c|c|c|c|c|c|c|}
\hline 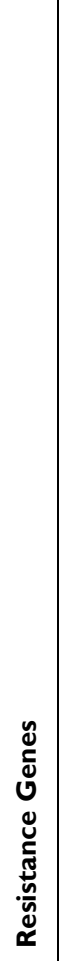 & 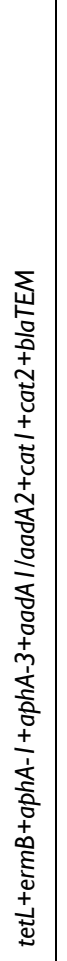 & 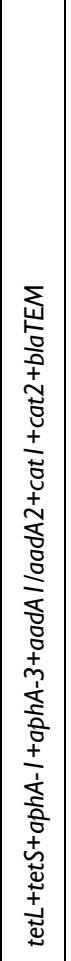 & 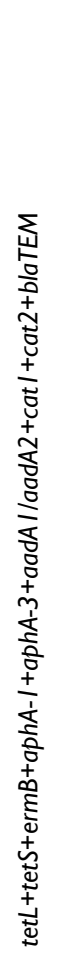 & 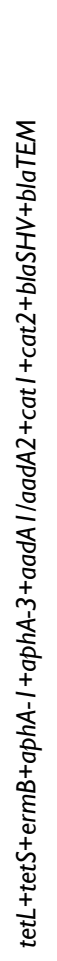 & 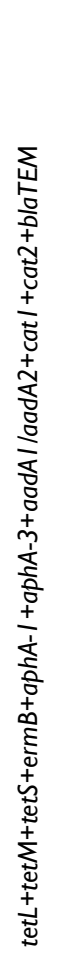 & 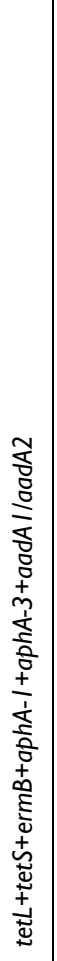 & 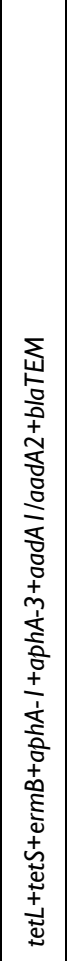 & 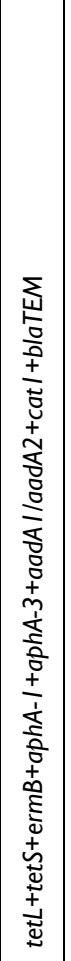 & 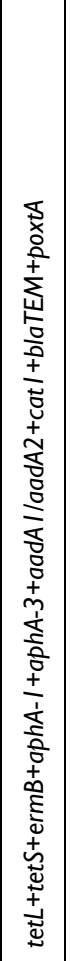 & 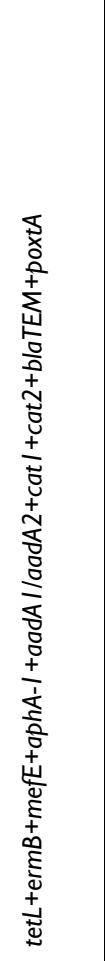 & 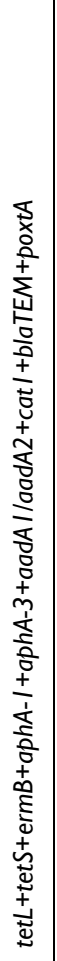 & 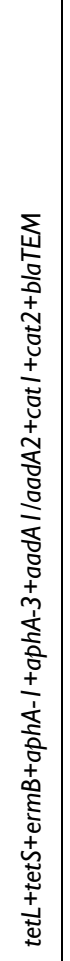 & 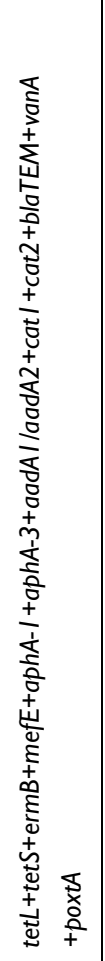 & 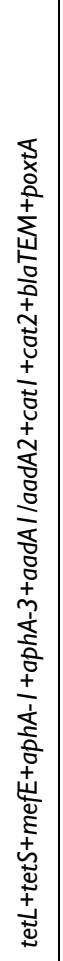 & 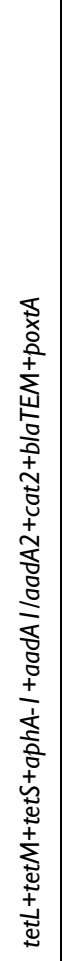 & 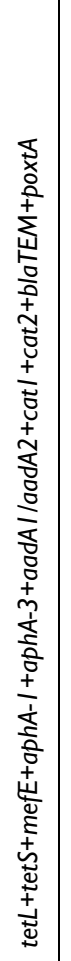 & 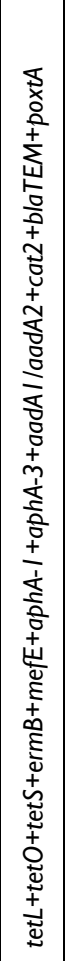 & 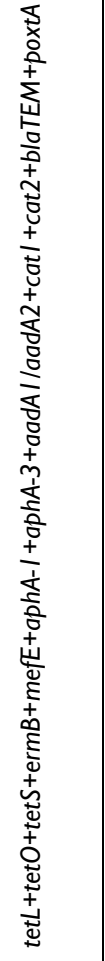 & 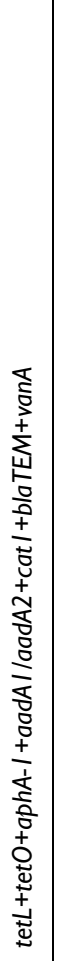 & 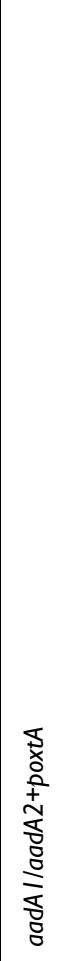 \\
\hline 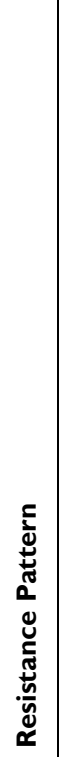 & 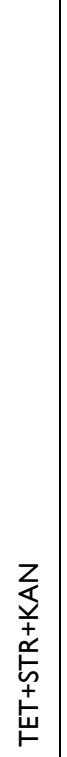 & 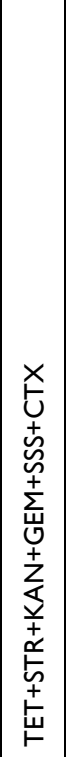 & 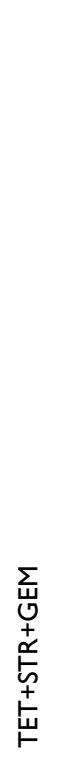 & 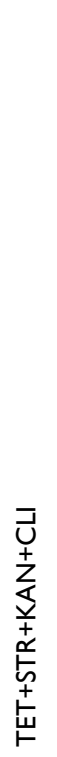 & 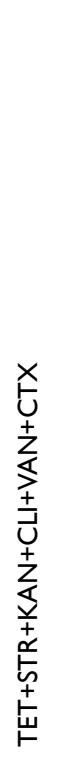 & 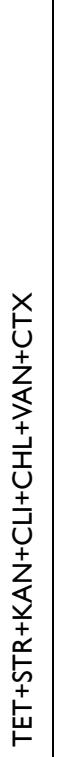 & 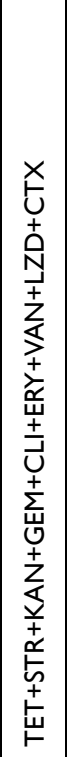 & 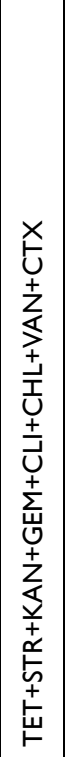 & 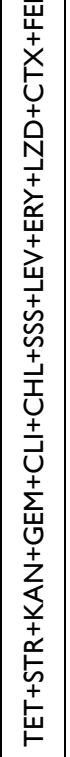 & 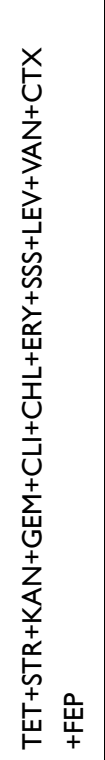 & 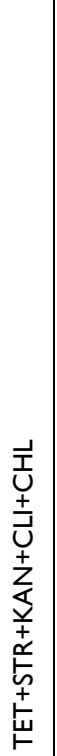 & 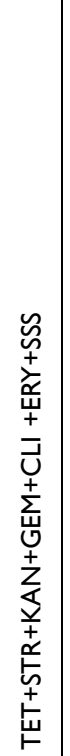 & 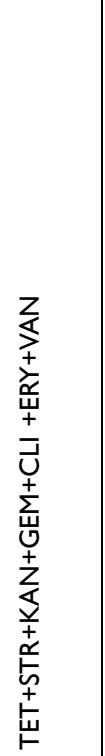 & 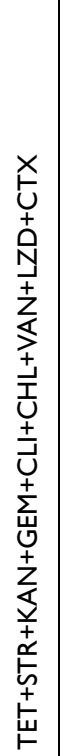 & 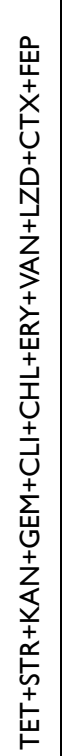 & 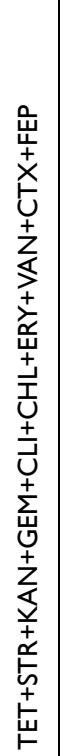 & 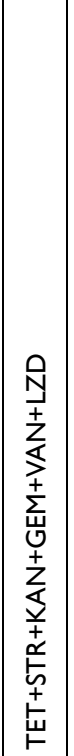 & 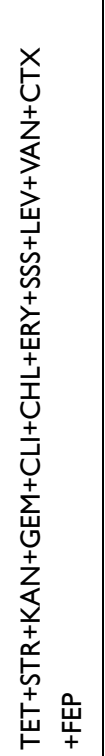 & 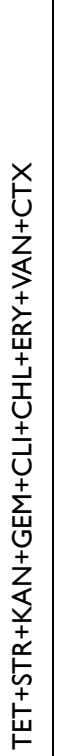 & 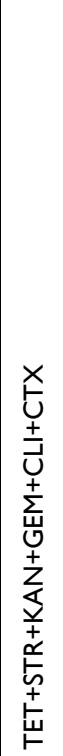 \\
\hline 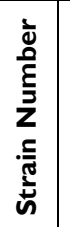 & \pm & $\stackrel{2}{\sim}$ & సి & $\hat{\sim}$ & $\stackrel{\infty}{\sim}$ & సి & ஓ & $\bar{m}$ & $\tilde{m}$ & $\stackrel{m}{m}$ & $\stackrel{ \pm}{m}$ & $\stackrel{m}{m}$ & లి & $\hat{m}$ & $\stackrel{\infty}{\infty}$ & ळे & q & $\bar{\sigma}$ & $\mathcal{F}$ & $q$ \\
\hline
\end{tabular}




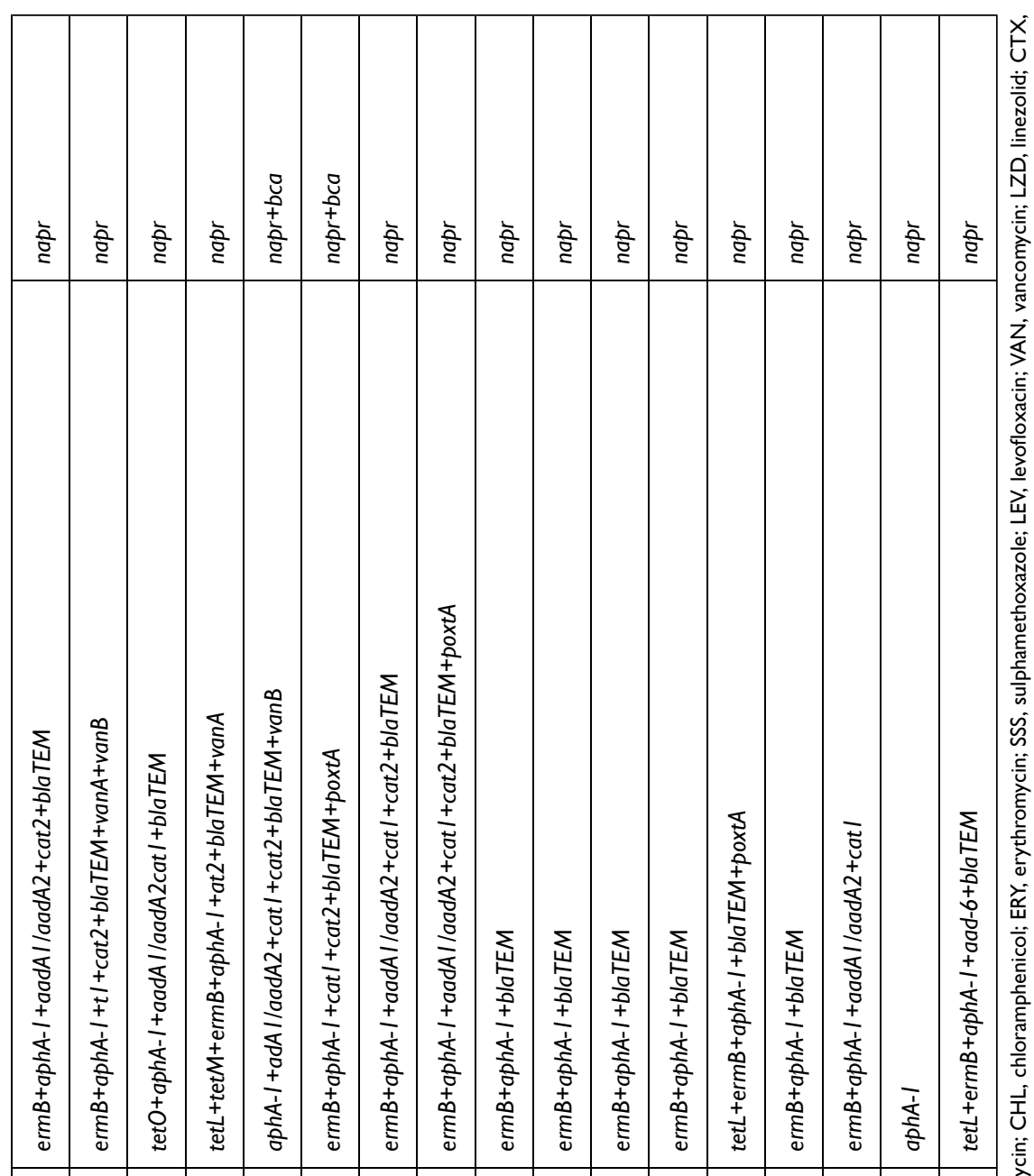

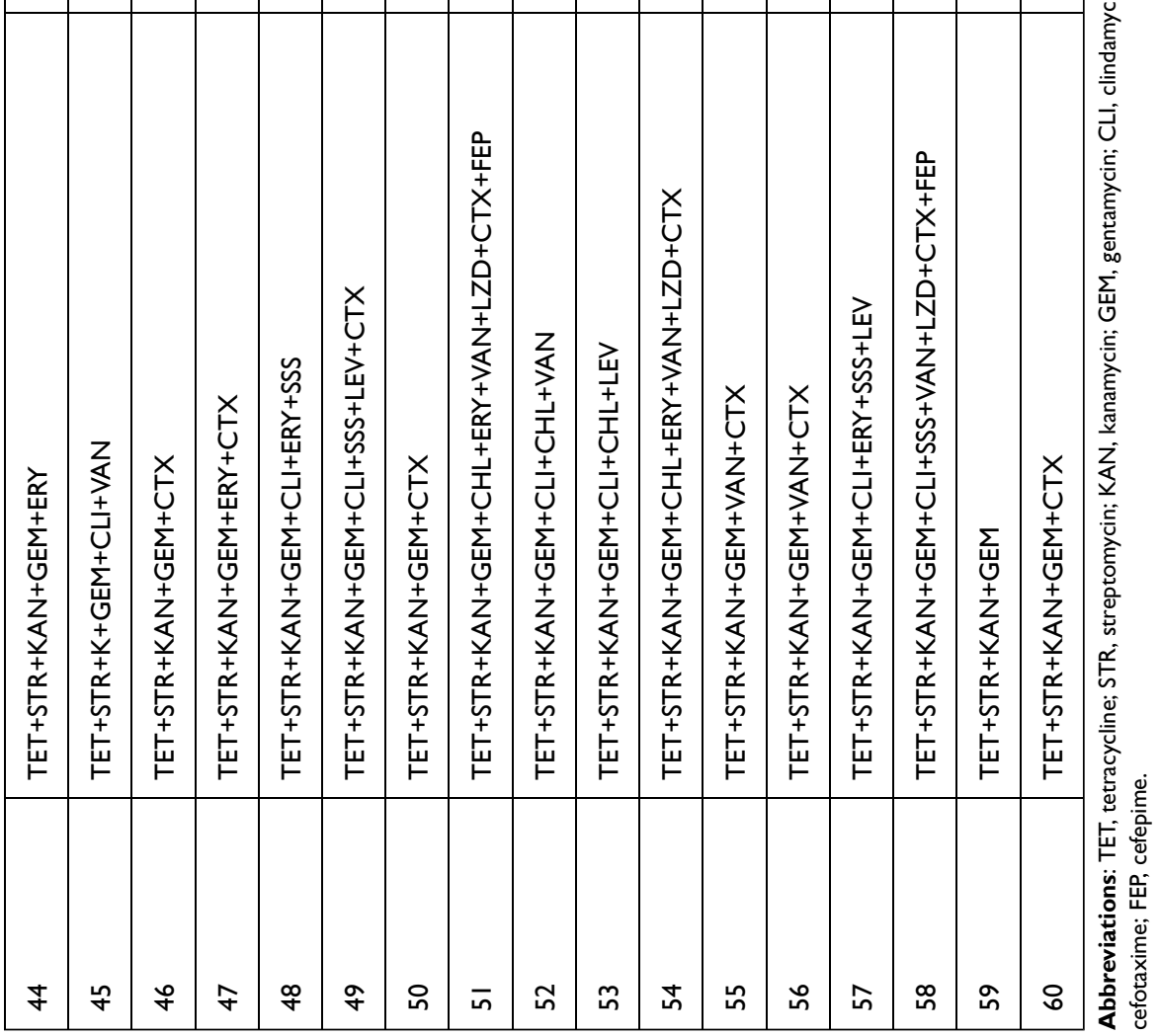


study carried the napr gene, which is higher than Kaczorek's finding, but only $16.67 \%$ have the eno gene, which is lower than their study. ${ }^{34}$ Hence, the napr gene encoding nephritisassociated plasminogen-binding receptor may be the main reason for $S$. dysgalactiae infection in dairy cows. ${ }^{35}$ Lamining-binding protein encoded by the $\operatorname{lmb}$ gene plays a key part in promoting adhesion to host laminin, which has been detected in $S$. dysgalactiae isolated from human sources. ${ }^{36}$ Consistent with the literature, we just found two strains harbored $l m b$. The $\beta$-hemolysin encoded by the $c y l$ gene is mainly involved in enhancing bacteria invasion of the host. ${ }^{37}$ Our result shows that $19.23 \%$ of strains have this gene, which is higher than the previous report. ${ }^{38}$ In addition, we also tested gene $b c a$ and $b a c$ severally encoding $\mathrm{C}$ alfa protein and $\mathrm{C}$ beta protein, a kind of antigen as a surface protein promoting the bacteria to enter the host cells. ${ }^{39,40}$ In this study, $6.67 \%$ of the isolates present the $b c a$ gene, but none had a $b a c$ gene, similar to the previous study. ${ }^{38}$ However, in contrast to earlier findings, Tian et al discovered both genes in streptococci. ${ }^{14}$ The $s c p B$ gene can code the surface enzyme ScpB, a C5a peptidase, which can hinder the aggregation of neutrophils and combine with fibronectin to promote bacterial invasion of epithelial cells. ${ }^{41}$ The expression of the $s c p B$ gene is one of the main determinants of severe neonatal infection caused by Streptococcus $B .{ }^{42}$ In our study, $20 \%$ of $S$. dysgalactiae carried the $s c p B$ gene, which may be an important reason for causing clinical mastitis in dairy cows, and further studies are needed to confirm it. CAMP factors are encoded by the $c f b$ gene, which can form pores in the host-cell membrane, mainly in S. agalactiae. ${ }^{43}$ We discovered $36.67 \%$ of $S$. dysgalactiae isolates had the $c f b$ gene against a previous report that only found it in S. agalactiae. ${ }^{38}$ S. agalactiae can transfer its genetic material to $S$. dysgalactiae to adapt to the bovine environment. ${ }^{44}$ And other studies also prove that virulence factors can be transferred between bacteria through the food chain, posing a serious threat to public health. ${ }^{45,46}$ It may lead to complex virulence factors in Streptococcus, which could make controlling, treatment and prevention of bovine mastitis difficult in the future.

\section{Conclusion}

In conclusion, this study reveals that the prevalence of S. dysgalactiae is not high but with a high level of resistance to frequently used antibiotics across the surveyed dairy farms. Therefore, it is suggested that susceptibility test should be used as a part of diagnosis to guide selecting the appropriate drugs. And in this area, the napr gene is the major invasive factor in
S. dysgalactiae to cause clinical mastitis, which largely affects the course and treatment of bovine mastitis. These findings provide a reference for public health security and convey a better understanding of the bacteria's main virulence mechanisms for further study, contributing to the development of targeted prevention programs and the establishment of clinic treatment programs in this region.

\section{Acknowledgments}

This study was supported by the National Key Research and Development Project of China (2017YFD0502200) and the National Natural Science Foundation of China (31802232).

\section{Disclosure}

The authors report no conflict of interests related to this work.

\section{References}

1. Gomes F, Henriques M. Control of bovine mastitis: old and recent therapeutic approaches. Curr Microbiol. 2016;72(4):377-382. doi:10.1007/s00284-015-0958-8

2. Sharma N, Rho GJ, Hong YH, et al. Bovine mastitis: an Asian perspective. Asian J Anim Vet Adv. 2012;7(6):454-476. doi:10.3923/ ajava.2012.454.476

3. Dabele DT, Borena BM, Admasu P, Gebremedhin EZ, Marami LM. Prevalence and risk factors of mastitis and isolation, identification and antibiogram of staphylococcus species from mastitis positive zebu cows in toke kutaye, cheliya, and dendi districts, west shewa zone, Oromia, Ethiopia. Infect Drug Resist. 2021;14:987-998. doi:10.2147/IDR.S295257

4. Abdelsalam M, Asheg A, Eissa AE. Streptococcus dysgalactiae: an emerging pathogen of fishes and mammals. Int J Vet Sci Med. 2013;1 (1):1-6. doi:10.1016/j.ijvsm.2013.04.002

5. Lundberg NAK, Aspán A, Börjesson S, Unnerstad HE, Waller KP. Udder infections with Staphylococcus aureus, Streptococcus dysgalactiae, and Streptococcus uberis at calving in dairy herds with suboptimal udder health. J Dairy Sci. 2016;99(3):2102-2117. doi:10.3168/jds.2015-9487

6. Bi YL, Wang YJ, Qin Y, et al. Prevalence of bovine mastitis pathogens in bulk tank milk in China. PLoS One. 2016;11(5):e0155621. doi:10.1371/journal.pone.0155621

7. Gao J, Barkema HW, Zhang LM, et al. Incidence of clinical mastitis and distribution of pathogens on large Chinese dairy farms. $J$ Dairy Sci. 2017;100(6):4797-4806. doi:10.3168/jds.2016-12334

8. Hogan J, Smith KL. Managing Environmental Mastitis. Vet Clin North Am Food Anim Pract. 2012;28(2):217-224. doi:10.1016/j. cvfa.2012.03.009

9. Günther M, Röhrle O, Haeufle DFB, Schmitt S. Spreading out Muscle Mass within a Hill-Type Model: a Computer Simulation Study. Comput Math Methods Med. 2012;2012:1-13. doi:10.1155/ 2012/848630

10. Yang F, Zhang S, Shang X, et al. Short communication: antimicrobial resistance and virulence genes of Enterococcus faecalis isolated from subclinical bovine mastitis cases in China. J Dairy Sci. 2019;102 (1):140-144. doi:10.3168/jds.2018-14576 
11. Stevens M, Piepers S, De Vliegher S. Mastitis prevention and control practices and mastitis treatment strategies associated with the consumption of (critically important) antimicrobials on dairy herds in Flanders, Belgium. J Dairy Sci. 2016;99(4):2896-2903. doi:10.3168/ jds.2015-10496

12. Vliegher SD, Ohnstad I, Piepers S. Management and prevention of mastitis: a multifactorial approach with a focus on milking, bedding and data-management. $J$ Integr Agric. 2018;17(6):1214-1233. doi:10.1016/S2095-3119(17)61893-8

13. Zhang SY, Piepers S, Shan R, et al. Phenotypic and genotypic characterization of antimicrobial resistance profiles in Streptococcus dysgalactiae isolated from bovine clinical mastitis in 5 provinces of China. J Dairy Sci. 2018;101(4):3344-3355. doi:10.3168/jds.201714031

14. Tian XY, Zheng N, Han RW, et al. Antimicrobial resistance and virulence genes of Streptococcus isolated from dairy cows with mastitis in China. Microb Pathog. 2019;131:33-39. doi:10.1016/j. micpath.2019.03.035

15. Calvinho LF, Almeida RA, Oliver SP. Potential virulence factors of Streptococcus dysgalactiae associated with bovine mastitis. Vet Microbiol. 1998;61(1-2):93-110. doi:10.1016/S0378-1135(98) 00172-2

16. Lundberg A, Nyman A, Unnerstad HE, Waller KP. Prevalence of bacterial genotypes and outcome of bovine clinical mastitis due to Streptococcus dysgalactiae and Streptococcus uberis. Acta Vet Scand. 2014;56(1):80. doi:10.1186/s13028-014-0080-0

17. Clinical and Laboratory Standards Institute (CLSI). Performance Standards for Antimicrobial Disk and Dilution Susceptibility Tests for Bacteria Isolated from Animals. 5th ed. Wayne, USA: CLSI standard VET01.Clinical and Laboratory Standards Institute; 2018.

18. Koivula M, Pitkälä A, Pyaörälä S, Mäntysaari EA. Distribution of bacteria and seasonal and regional effects in a new database for mastitis pathogens in Finland. Acta Agric Scand a Anim Sci. 2007;57(2):89-96. doi:10.1080/09064700701488941

19. Lakew M, Tolosa T, Tigre W. Prevalence and major bacterial causes of bovine mastitis in Asella, South Eastern Ethiopia. Trop Anim Health Prod. 2009;41(7):1525-1530. doi:10.1007/s11250-0099343-6

20. Botrel MA, Haenni M, Morignat E, Sulpice P, Madec JY, Calavas D. Distribution and antimicrobial resistance of clinical and subclinical mastitis pathogens in Dairy Cows in Rhône-Alpes, France. Foodborne Pathog Dis. 2010;7(5):479-487. doi:10.1089/ fpd.2009.0425

21. Rato MG, Bexiga R, Florindo C, Cavaco LM, Vilela CL, SantosSanches I. Antimicrobial resistance and molecular epidemiology of streptococci from bovine mastitis. Vet Microbiol. 2013;161(34):286-294. doi:10.1016/j.vetmic.2012.07.043

22. Yang F, Wang Q, Wang X, et al. Genetic characterization of antimicrobial resistance in Staphylococcus aureus isolated from bovine mastitis cases in Northwest China. J Integr Agric. 2016;15 (12):2842-2847. doi:10.1016/S2095-3119(16)61368-0

23. MOA. Ministry of Agriculture of the People's Republic of China. Announcement No.1997 of the Ministry of Agriculture. Ministry of Agriculture of the People's Republic of China; 2013. Available from: http://www.moa.gov.cn/nybgb/2013/dshiq/201712/t20171227 6126416.htm. Accessed April 11, 2021.

24. Cheng J, Qu W, Barkema HW, et al. Antimicrobial resistance profiles of 5 common bovine mastitis pathogens in large Chinese dairy herds. J Dairy Sci. 2019;102(3):2416-2426. doi:10.3168/jds.2018-15135

25. Stogios PJ, Savchenko A. Molecular mechanisms of vancomycin resistance. Protein Sci. 2020;29(3):654-669. doi:10.1002/pro.3819

26. De Oliveira AP, Watts JL, Salmon SA, Aarestrup FM. Antimicrobial Susceptibility of Staphylococcus aureus Isolated from Bovine Mastitis in Europe and the United States. J Dairy Sci. 2000;83 (4):855-862. doi:10.3168/jds.S0022-0302(00)74949-6
27. Haveri M, Suominen S, Rantala L, Honkanen-Buzalski T, Pyörälä S. Comparison of phenotypic and genotypic detection of penicillin $\mathrm{G}$ resistance of Staphylococcus aureus isolated from bovine intramammary infection. Vet Microbiol. 2005;106(1-2):97-102. doi:10.1016/j.vetmic.2004.12.015

28. Park YK, Nho SW, Shin GW, et al. Antibiotic susceptibility and resistance of Streptococcus iniae and Streptococcus parauberis isolated from olive flounder (Paralichthys olivaceus). Vet Microbiol. 2009;136(1-2):76-81. doi:10.1016/j.vetmic.2008.10.002

29. Fernández-Aceñero MJ, Fernández-López P. Cutaneous lesions associated with bacteremia by Streptococcus dysgalactiae. J Am Acad Dermatol. 2006;55(5):S91-S92. doi:10.1016/j.jaad.2005.01.097

30. Preez JHD. Bovine mastitis therapy and why it fails: continuing education. J S Afr Vet Assoc. 2000;71(3):201-208. doi:10.4102/ jsava.v71i3.714

31. Fulde M, Steinert M, Bergmann S. Interaction of streptococcal plasminogen binding proteins with the host fibrinolytic system. Front Cell Infect Microbiol. 2013;3(NOV):85. doi:10.3389/ fcimb.2013.00085

32. Pancholi V. Multifunctional $\alpha$-enolase: its role in diseases. Cell $\mathrm{Mol}$ Life Sci. 2001;58(7):902-920. doi:10.1007/PL00000910

33. Lottenberg R, Broder CC, Boyle MDP, Kain SJ, Schroeder BL, Curtiss R. Cloning, sequence analysis, and expression in Escherichia coli of a streptococcal plasmin receptor. J Bacteriol. 1992;174(16):5204-5210. doi:10.1128/jb.174.16.5204-5210.1992

34. Kaczorek E, Małaczewska J, Wójcik R, Siwicki AK. Biofilm production and other virulence factors in Streptococcus spp. isolated from clinical cases of bovine mastitis in Poland. BMC Vet Res. 2017;13 (1):398. doi:10.1186/s12917-017-1322-y

35. Abdelsalam M, Fujino M, Eissa AE, Chen SC, Warda M. Expression, genetic localization and phylogenic analysis of NAPlr in piscine Streptococcus dysgalactiae subspecies dysgalactiae isolates and their patterns of adherence. $J$ Adv Res. 2015;6(5):747-755. doi:10.1016/j.jare.2014.05.005

36. Ciszewski M, Szewczyk EM. Potential Factors Enabling Human Body Colonization by Animal Streptococcus dysgalactiae subsp. equisimilis Strains. Curr Microbiol. 2017;74(5):650-654. doi:10.1007/s00284-017-1232-z

37. Armistead B, Whidbey C, Iyer LM, et al. The cyl Genes Reveal the Biosynthetic and Evolutionary Origins of the Group B Streptococcus Hemolytic Lipid, Granadaene. Front Microbiol. 2020;10:3123-3133. doi: 10.3389/fmicb.2019.03123

38. Ding YX, Zhao JL, He XL, et al. Antimicrobial resistance and virulence-related genes of Streptococcus obtained from dairy cows with mastitis in Inner Mongolia, China. Pharm Biol. 2016;54 (1):162-167. doi:10.3109/13880209.2015.1025290

39. Lindahl G, Stålhammar-Carlemalm M, Areschoug T. Surface proteins of Streptococcus agalactiae and related proteins in other bacterial pathogens. Clin Microbiol Rev. 2005;18(1):102-127. doi:10.1128/ CMR.18.1.102-127.2005

40. Beigverdi R, Jabalameli F, Mirsalehian A, et al. Virulence factors, antimicrobial susceptibility and molecular characterization of streptococcus agalactiae isolated from pregnant women. Acta Microbiol Immunol Hung. 2014;61(4):425-434. doi:10.1556/AMicr.61.2014.4.4

41. Beckmann C, Waggoner JD, Harris TO, Tamura GS, Rubens CE. Identification of novel adhesins from group B streptococci by use of phage display reveals that C5a peptidase mediates fibronectin binding. Infect Immun. 2002;70(6):2869-2876. doi:10.1128/ IAI.70.6.2869-2876.2002

42. Jain B, Tewari A, Bhandari BB, Jhala MK. Antibiotic resistance and virulence genes in Streptococcus agalactiae isolated from cases of bovine subclinical mastitis. Vet Arch. 2012;82(5):423-432.

43. Dmitriev A, Shakleina E, Tkáčiková L, Mikula I, Totolian A. Genetic heterogeneity of the pathogenic potentials of human and bovine group B streptococci. Folia Microbiol (Praha). 2002;47 (3):291-295. doi:10.1007/BF02817655 
44. Richards VP, Lang P, Pavinski Bitar PD, et al. Comparative genomics and the role of lateral gene transfer in the evolution of bovine adapted Streptococcus agalactiae. Infect Genet Evol. 2011;11(6):1263-1275. doi:10.1016/j.meegid.2011.04.019

45. Aslam M, Diarra MS, Checkley S, Bohaychuk V, Masson L. Characterization of antimicrobial resistance and virulence genes in Enterococcus spp. isolated from retail meats in Alberta, Canada. Int J Food Microbiol. 2012;156(3):222-230. doi:10.1016/j. ijfoodmicro.2012.03.026
46. Iweriebor BC, Obi LC, Okoh AI. Virulence and antimicrobial resistance factors of Enterococcus spp. isolated from fecal samples from piggery farms in Eastern Cape, South Africa. BMC Microbiol. 2015;15(1):136-146. doi:10.1186/s12866-015-0468-7

47. Zhang H, Yang F, Li X-P. Detection of antimicrobial resistance and virulence-related genes in Streptococcus uberis and Streptococcus parauberis isolated from clinical bovine mastitis cases in northwestern China. J Integr Agric. 2020;19(11):2784-2791. doi:10.1016/ S2095-3119(20)63185-9

\section{Publish your work in this journal}

Infection and Drug Resistance is an international, peer-reviewed openaccess journal that focuses on the optimal treatment of infection (bacterial, fungal and viral) and the development and institution of preventive strategies to minimize the development and spread of resistance. The journal is specifically concerned with the epidemiology of antibiotic resistance and the mechanisms of resistance development and diffusion in both hospitals and the community. The manuscript management system is completely online and includes a very quick and fair peerreview system, which is all easy to use. Visit http://www.dovepress.com/ testimonials.php to read real quotes from published authors. 